ORIGINAL ARTICLE

\title{
Study of sexual behaviours with different types of estrus synchronization protocols in Boer goats
}

\author{
Suraya Mohamad Salleh ${ }^{1}$, Abdul Mu'in Hassan Basri ${ }^{1}$, Halimatun Yaakub * (D) \\ ${ }^{1}$ Department of Animal Science, Faculty of Agriculture, Universiti Putra Malaysia, 43400 Serdang, Selangor, Malaysia
}

How to cite: Salleh SM, Basri AMH, Yaakub H. Study of sexual behaviours with different types of estrus synchronization protocols in Boer goats. Anim Reprod. 2021;18(3):e20200038. https://doi.org/10.1590/19843143-AR2020-0038

\begin{abstract}
There is still a lack of information on estrus synchronization in goats. Understanding the estrus synchronization protocols and the subsequent effects is important to improve the efficiency of assisted reproductive technologies (ARTs) and subsequently would improve the breeding procedures. This study will help in determining the most suitable estrus synchronization protocol and understand better the effect on the sexual behaviour and hormonal effects in goats. A total of 127 Boer does were used and divided into three groups with different duration of CIDR insertion intravaginally either for 14 (two groups) or 9 days (one group). Approximately $0.5 \mathrm{ml}$ Estrumate $^{\circledR}$ (PG) was administered intramuscularly to all groups at CIDR removal, and only groups PMSG14 and PMSG9 were administered with $200 \mathrm{IU}$ of Pregnant Mare Serum Gonadotropin (PMSG) intramuscularly. Estrus signs were observed at $4 \mathrm{~h}$ intervals and blood samples were collected for progesterone and luteinizing hormone determination. The percentage of does in estrus within 24 to $72 \mathrm{~h}$ post CIDR removal was significantly higher $(P<0.05)$ in groups with PMSG compared to the group without the PMSG. The numbers of does display estrus signs within 24 to $28 \mathrm{~h}$ post CIDR removal were significantly higher $(P<0.05)$ in group shorter period ( 9 days) compared to groups with 14 days CIDR. The P4 concentrations at 24 hours post CIDR removals and LH concentration was not significantly different $(P>0.05)$ in all groups. The time of the $\mathrm{LH}$ peak in the group without the PMSG was significantly delayed $(P<0.05)$ when compared to group 9 days CIDR and administered with PMSG. It is recommended to use the treatment for 9 days CIDR since the estrous cycle can be shortened.
\end{abstract}

Keywords: estrus synchronization, progesterone, luteinizing hormone, Controlled Internal Drug Release (CIDR), goats.

\section{Introduction}

Goat meat production is among the important meat besides beef and mutton. Breeds such as Boer, Savannah, and Red Kalahari can adapt to different environmental conditions and grow rapidly with excellent carcass quality (Lu, 2001; Rahman et al., 2008b; Hifzan et al., 2015; Maynard, 2015). A good breeding program needs to be developed to maintain and continuously produce these breeds efficiently.

Assisted Reproductive Technologies (ARTs) have been used in reproductive and breeding protocols to maximize the improvement and the utilization of these breeds (Rahman et al., 2008b). The most common technologies being used are artificial insemination (Al), superovulation, and embryo transfer. Estrus synchronization is an important prerequisite to facilitate the use of these biotechnology techniques efficiently (Martinez et al., 2002). Estrus synchronization in goats has not much attention since early

*Corresponding author: hali@upm.edu.my

Received: November 10, 2020. Accepted: July 13, 2021.

Financial support: This project was funded by Exploratory Research Grant Scheme (ERGS/1/11/STWN/UPM/02/15) from the Ministry of Education, Malaysia. Conflict of interest: The authors have no conflict of interest to declare. 
2000. Hence, related studies are needed to update and ensure the effectiveness of certain protocols for more efficient livestock production specifically in goats.

Many types of research related to estrus synchronization have been conducted in cattle and sheep to determine the best protocol for estrus synchronization. Rahman et al. (2008a) reviewed several estrus synchronization protocols that have been used since 1986. However, the information on estrus synchronization in goats is limited especially in tropical countries. Hence, the present study will contribute to the understanding of different estrus synchronization protocols on estrus behaviour and hormonal profiles. Estrus synchronization is a very important protocol in animal breeding purposes generally. Most importantly, it helps farmers to breed their animals at the same time as well as helps researchers to control and conduct a test at the same time to minimize environmental effects.

The usage of controlled internal drug release (CIDR) along with prostaglandin (PG) to synchronize estrus is a common practice in estrus synchronization in ruminants. Oliveira et al. (2001) and Zeleke et al. (2005) reported that the usage of CIDR was more effective when used along with PG and pregnant mare serum gonadotrophin (PMSG). This resulted in a $100 \%$ fertility or success rate when natural mating was used. Oliveira et al. (2001) and Salleh et al. (2014) showed that the addition of PMSG significantly increased the number of animals on estrus. In tropical countries especially, there is still a lack of information on the effects of estrus synchronization using CIDR in goats. Understanding this would increase the efficiency of goat production, by reducing the problem of estrus detection, labour cost, and increase the uniformity of the kids (Oliveira et al., 2011).

The present study was conducted to find the best protocol of estrus synchronization and understand better the differences between different estrus synchronization protocols on the hormones and estrus behaviour under tropical conditions.

\section{Materials and methods}

\section{Animals and treatment}

The experimental animal procedures were following the animal research guidelines according to Kilkenny et al. (2010) and also the guidelines from Universiti Putra Malaysia. Trained staff and veterinarian were involved in blood samplings and monitoring the experimental animals to ensure minimal stress during the implementation of all experimental procedures.

The study was carried out at Advance Reproductive Biotechnology (ARB) farm, Kluang, Johor, Malaysia. A total of 127 cyclic Boer goats ranging in age from 4 to 6 years old, weighing 35 to $60 \mathrm{~kg}$, and presenting a body condition score of 3.0 to 4.0 was used. All the experimental does were multiparous which previously gave birth more than once, and selected according to their health and fertility records. The goats were reared under semiintensive management, grazing on Brachiaria humidicola and Panicum maximum pasture from 10 am until $4 \mathrm{pm}$ and feeding on commercial pellets about $1 \%$ of body weight twice daily, before and after grazing. Ad libitum of clean water was provided every day. The does were randomly allocated to three treatment groups of estrus synchronization protocols.

Control Internal Drug Release (CIDR) (Pfizer ${ }^{\circledR}$, New Zealand) was inserted into the vagina of each goat for 14 days for estrus treatments PG14 (control) and PMSG14, and 9 days for estrus treatment PMSG9. Approximately $0.5 \mathrm{ml}$ Estrumate ${ }^{\circledR}$ (Cloprostenol $250 \mathrm{mg} / \mathrm{mL}$ ) was injected intramuscularly to the does in all treatment groups during the withdrawal of the CIDR. Approximately 200 IU of Pregnant Mare Serum Gonadotropin (PMSG) FOLLIGON ${ }^{\circledR}$ were injected intramuscularly to does in group PMSG14 and PMSG9 at CIDR withdrawal. Figure 1 shows the workflow of the experiment start from CIDR insertion to cessation of treatment and observations. 


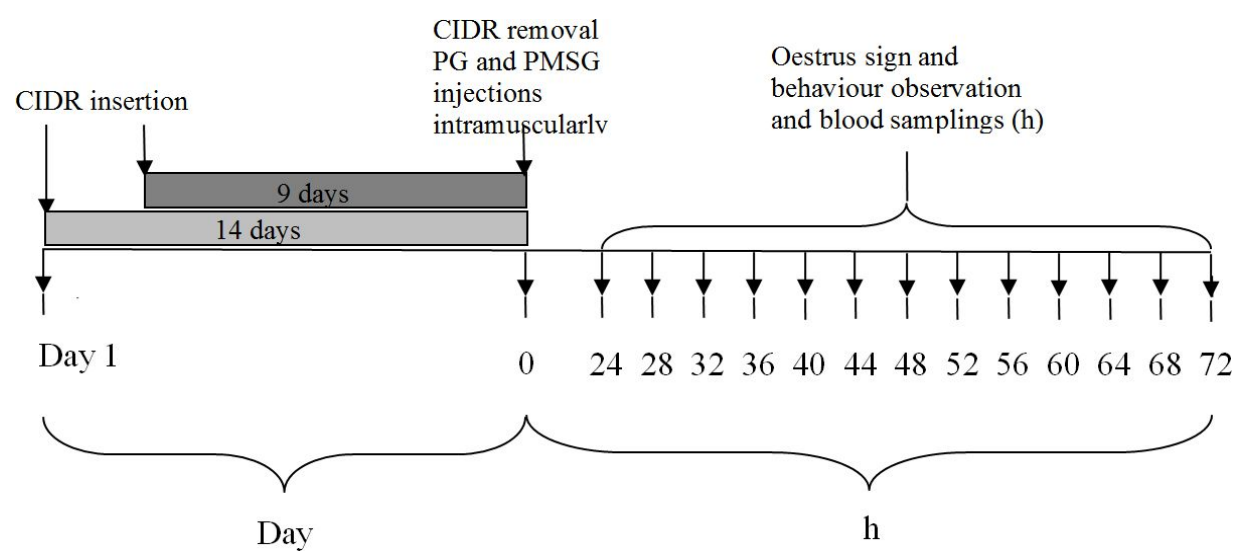

Figure 1. Diagram showing the time of the estrus synchronization, blood samplings, and estrus behaviour observation.

\section{Estrus signs observations}

Estrus signs were observed 48 hours, post CIDR removal at 4 hours intervals (at 24, 28, 32 , $36,40,44,48,52,56,60,64,68$, and $72 \mathrm{~h}$ after CIDR removal). Each observation was conducted for at least 30 minutes. The estrus behaviour that has been recorded were mounting each other, standing to be mounted, tail wagging, bleating, and sniffing. The clinical signs of estrus are reddening of vulva, swollen vulva and discharge from vulva.

\section{Blood sampling and processing}

Twelve does from each estrus synchronization protocol group were randomly selected for blood sampling. Approximately $4 \mathrm{ml}$ of blood sample was collected from the jugular vein using a $21 \mathrm{G}$ needle attached to a plain vacutainer tube (BD ${ }^{\circledR}$ vacutainer, Plymouth, UK). Blood sampling was done before CIDR insertion, before CIDR removal, immediately after CIDR removal, and every 4 hours after CIDR removal until 48 hours. Blood was chilled overnight in the refrigerator $\left(4^{\circ} \mathrm{C}\right)$ and then thawed at room temperature. Serum from the blood was separated by centrifugation at $500 \mathrm{~g}$ for 15 minutes. Then, the serum was transferred into a microcentrifuge tube and stored at $-20^{\circ} \mathrm{C}$ before $\mathrm{P} 4$ and $\mathrm{LH}$ analysis.

\section{Serum analysis for P4 and LH}

The serum samples collected before CIDR insertion, and withdrawal and 24 hours after withdrawal, were used to determine the P4 concentration. The serial serum samples collected at 24 hours after CIDR removal and thereafter at 4 hours intervals were used to determine LH concentration. The P4 and $\mathrm{LH}$ concentrations were determined using Enzyme-linked Immunosorbent Assay (ELISA) kit (Cusabio ${ }^{\circledR}$, China). The concentration of the hormones was determined by optical density. The ELISA plate was read at $450 \mathrm{~nm}$ using a microtiter plate reader (Bio-Rad ${ }^{\circledR}$ iMark Microplate reader). The coefficient of variation (CV) of intra-assay was $4.4 \%$ and inter-assay was and $11.7 \%$. The minimum detectable levels were $0.2 \mathrm{ng} / \mathrm{ml}$ for P4 and $0.24 \mathrm{mlU} / \mathrm{ml}$ for $\mathrm{LH}$.

\section{Statistical analysis}

Data on estrus observations (does in estrus and specific estrus behaviour) were compared using the frequency procedure of SAS and Chi-square $\left(\chi^{2}\right)$ test of independence. Data on LH and P4 hormones were analyzed using the GLM procedure of SAS software. Duncan Multiple Range Test (DMRT) was used to compare the mean. All statistical comparisons were set at a 0.05 level of significance. 


\section{Compliance with ethical standards}

The experimental animal procedures were following the animal research guidelines.

\section{Results}

The duration of estrus interval between CIDR removal and the start of estrus, as well as the end of estrus (Table 1), showed no significant difference ( $P>0.05$ ) among the treatment groups. However, treatment group PMSG9 showed better results when compared with treatment groups with 14 days of CIDR insertion. The interval from CIDR removal to the onset of estrus was shortest in treatment PMSG9 compared with the other two treatments. In addition, the does in treatment PMSG9 also had the longest duration of estrus expression than the other two treatment groups.

Table 1. Percentage of goats that responded to estrus synchronization treatments, the interval from CIDR removal to start of estrus, and end of estrus, and duration of estrus.

\begin{tabular}{cccc} 
Treatments & \multicolumn{3}{c}{ Estrus Synchronization Protocol } \\
& PMSG14 & PG14 & PMSG9 \\
\hline \% does responded (n) & 41 & 42 & 41 \\
\hline $\begin{array}{c}\text { Time interval from CIDR removal and } \\
\text { start of estrus (h) }\end{array}$ & $97.56(40)^{\mathrm{a}}$ & $80.95(34)^{\mathrm{b}}$ & $100.0(41)^{\mathrm{a}}$ \\
\hline $\begin{array}{c}\text { Time interval from CIDR removal and } \\
\text { end Estrus(h) }\end{array}$ & $29.2 \pm 0.90$ & $28.9 \pm 0.99$ & $27.7 \pm 0.70$ \\
\hline Duration of estrus (h) & $54.1 \pm 1.37$ & $53.2 \pm 2.19$ & $57.3 \pm 1.18$ \\
\hline
\end{tabular}

Means of a trait sharing common superscripts are not significantly different $(\mathrm{P}>0.05)$.

Figure 2 shows the distribution of the start of estrus behaviour and signs from $24 \mathrm{~h}$ after CIDR removal. Most of the does display the estrus behaviour as early as $24 \mathrm{~h}$ and as late as $52 \mathrm{~h}$ after CIDR removal. About $81 \%$ of does from treatment PMSG9 started showing the estrus behaviour at $24^{\text {th }} \mathrm{h}(\mathrm{n}=18)$ and $28^{\text {th }} \mathrm{h}(\mathrm{n}=17)$ after CIDR removal. For treatments, PMSG14 and PG14 only about of the does $69 \%$ and $61 \%$ respectively, showed estrus behaviour by these times. The does start showing estrus behaviour for treatment groups with PMSG administration was the latest at $44 \mathrm{~h}$. For the treatment group without the PMSG administration, some does start showing estrus behaviour only at 48-52 $\mathrm{h}$ after CIDR removal.

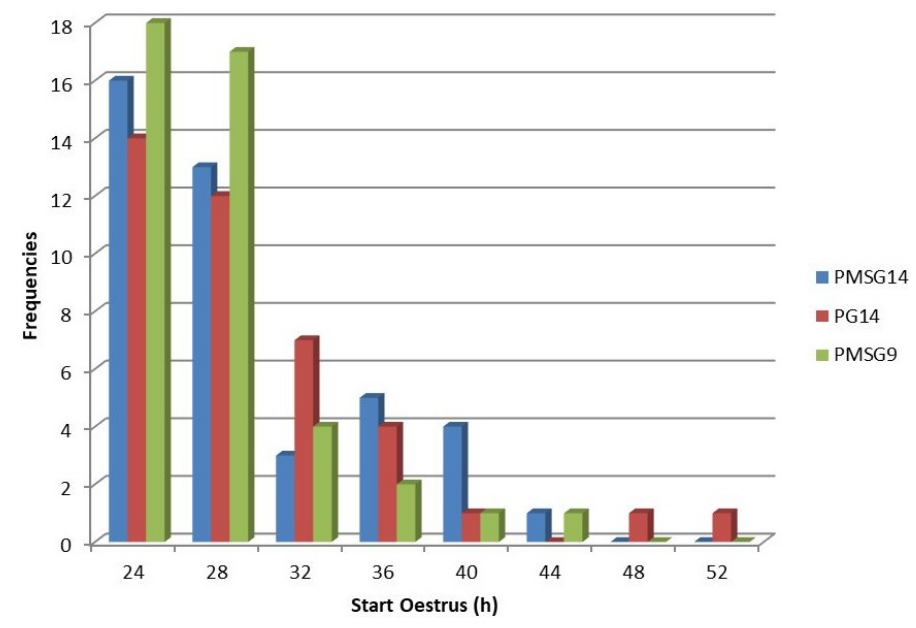

Figure 2. Distribution of time of does start their estrus signs after CIDR removal

Figure 3 shows the distribution time of does end of the estrus signs. The range of end estrus was as early as $32 \mathrm{~h}$ after CIDR removal and as late as $72 \mathrm{~h}$ after CIDR removal. The highest 
frequencies of does end up their estrus sign were at $52 \mathrm{~h}$ after CIDR removal. In total, 43, 32, and $24 \%$ of does in treatment group PMSG9, PMSG14, PG14, respectively, end their estrus at $52 \mathrm{~h}$ after the CIDR removal. The rest of them does end their estrus behaviours and signs at several hours, which are about $10 \%$ of each treatment group end up at each hour of observation.

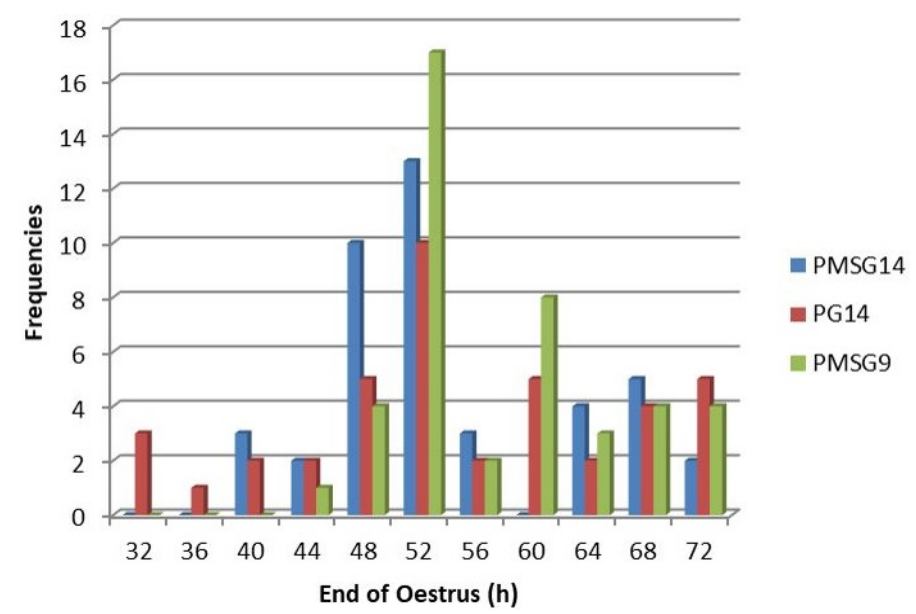

Figure 3. Distribution of time of does end their estrus signs after CIDR removal.

The duration of estrus was calculated from the time each doe starts showing estrus until the end of estrus. The duration of estrus ranged from $0 \mathrm{~h}$ (no sign of estrus) to $48 \mathrm{~h}$ (Figure 4). It shows, about $15 \%$ of does from the treatment group without the PMSG administration have not shown their estrus signs. A larger number of does in treatment groups with PMSG administration showed estrus duration for about $28 \mathrm{~h}$. The frequency of estrus duration in group PG14 was inconsistent and ranged from 0 to $48 \mathrm{~h}$. However, $20 \%$ of does in this group had $24 \mathrm{~h}$ estrus duration.

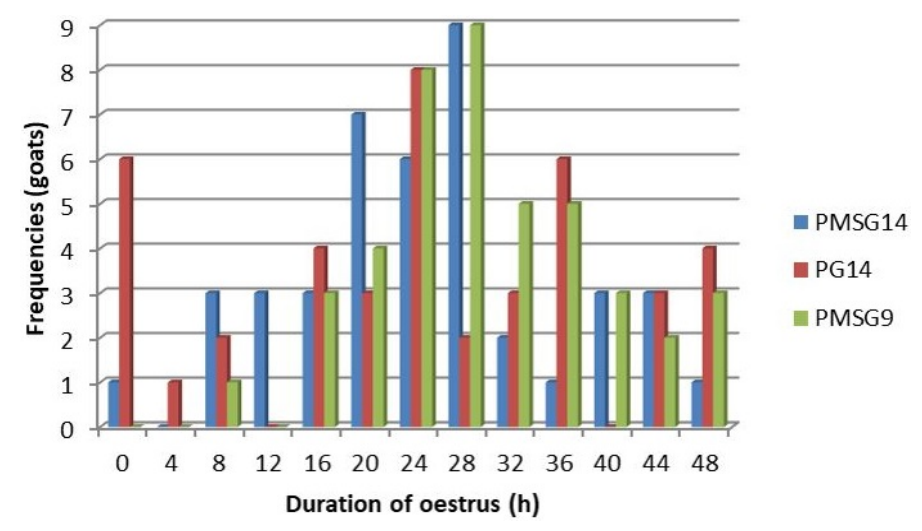

Figure 4. Distribution of estrus duration (h).

Table 2 gives the number of expressing estrus behaviour from $24 \mathrm{~h}$ to $72 \mathrm{~h}$ after CIDR removal under three estrus synchronization protocols. The most frequent behaviour exhibited by the does was tail wagging. Almost all of the does from the three treatment groups wagged their tails during estrus. Treatment groups with PMSG administration showed significantly $(P<0.05)$ greater percentages of does express mounting, standing to be mounted, tail wagging, and sniffing behaviours compared to the treatment group without PMSG administration. Other estrus signs such as vulva discharge, swollen vulva, and vocalizing were not significantly different $(P>0.05)$ among the treatment groups.

Table 2. Percentage (number) of does expressing different estrus signs. 


\begin{tabular}{cccc} 
& \multicolumn{3}{c}{ Estrus Synchronization Protocol } \\
& PMSG14 & PG14 & PMSG9 \\
\hline Behaviour expressed (\%) & & & \\
\hline Mounting & $69.05(29)^{\mathrm{a}}$ & $28.57(12)^{\mathrm{b}}$ & $65.12(28)^{\mathrm{a}}$ \\
\hline Standing & $69.05(29)^{\mathrm{a}}$ & $28.57(12)^{\mathrm{b}}$ & $72.09(31)^{\mathrm{a}}$ \\
\hline Tail wagging & $95.24(40)^{\mathrm{a}}$ & $83.33(35)^{\mathrm{b}}$ & $100(43)^{\mathrm{a}}$ \\
\hline Vulva Discharge & $52.38(22)^{\mathrm{a}}$ & $52.38(22)^{\mathrm{a}}$ & $62.79(27)^{\mathrm{a}}$ \\
\hline Swollen Vulva & $71.43(30)^{\mathrm{a}}$ & $66.67(28)^{\mathrm{a}}$ & $81.40(35)^{\mathrm{a}}$ \\
\hline Vocalizing & $23.81(10)^{\mathrm{a}}$ & $21.43(9)^{\mathrm{a}}$ & $37.21(16)^{\mathrm{a}}$ \\
\hline Sniffing & $23.81(10)^{\mathrm{a}}$ & $0.00(0)^{\mathrm{b}}$ & $13.95(6)^{\mathrm{a}}$ \\
\hline
\end{tabular}

a,bPercentage value with different superscript within the same row are significantly different $(P<0.05)$.

Table 3 shows the onset of estrus signs (mounting and standing to be mounted) behaviour after CIDR removal. Mounting behaviour showed no significant difference $(P>0.05)$ between the treatment groups. As for standing to be mounted, this occurred significantly later $(P<0.05)$ in the treatment without PMSG compared with groups with PMSG. Mounting and standing to be mounted behaviours were displayed at about the same time, about 32 to $44 \mathrm{~h}$ after CIDR removal.

Table 3. Mean of time between CIDR removal and receptivity behaviours (mounting and standing) behaviour ( $\mathrm{h} \pm \mathrm{SE})$.

\begin{tabular}{cccc} 
Treatment & PMSG14 & PG14 & PMSG9 \\
Mounting & $36.14 \pm 1.45^{\mathrm{a}}$ & $35.38 \pm 2.12^{\mathrm{a}}$ & $36.00 \pm 1.53^{\mathrm{a}}$ \\
\hline $\mathrm{n}$ & 29 & 13 & 25 \\
\hline Standing & $36.66 \pm 1.19^{\mathrm{a}}$ & $42.00 \pm 3.06^{\mathrm{b}}$ & $37.39 \pm 1.85^{\mathrm{a}}$ \\
\hline $\mathrm{n}$ & 29 & 12 & 31 \\
\hline
\end{tabular}

a,b Mean values within the same row with different superscripts are significantly different at $\mathrm{P}<0.05$.

There was no significant difference $(P>0.05)$ in $\mathrm{P} 4$ concentration among all time points of $\mathrm{P} 4$ concentration analysis. Progesterone concentration before CIDR insertion ranged between 0.56 and $8.14 \mathrm{ng} / \mathrm{ml}$. Twenty-four hours after the CIDR removal the concentration of the P4 hormone had generally declined except for the treatment group with 14 days CIDR insertion which were increases.

Table 4 shows the mean time of the occurrence of the LH peak from CIDR removal as well as the onset of estrus. The interval between CIDR removal and LH peak was significantly different $(P<0.05)$ between treatment groups PG14 and PMSG9, but the interval from estrus onset was not significantly different $(P>0.05)$.

Table 4. Intervals to LH peak occurrence, the interval from onset of estrus to $\mathrm{LH}$ peak $(\mathrm{h} \pm \mathrm{SE})$ and $\mathrm{LH}$ at peak $(\mathrm{mlU} / \mathrm{ml} \pm \mathrm{SE})$.

\begin{tabular}{|c|c|c|c|}
\hline Treatment & PMSG14 & PG14 & PMSG9 \\
\hline $\begin{array}{l}\text { Interval from CIDR removal to } \\
\qquad \mathrm{LH} \text { peak }(\mathrm{h}) \pm \mathrm{SE}\end{array}$ & $39.2 \pm 1.79^{a b}$ & $46.2 \pm 4.17^{a}$ & $37.2 \pm 1.89^{b}$ \\
\hline $\begin{array}{l}\text { Interval from onset of estrus to } \\
\qquad \mathrm{LH} \text { peak }(\mathrm{h}) \pm \mathrm{SE}\end{array}$ & $11.2 \pm 2.52^{a}$ & $16.0 \pm 3.46^{a}$ & $9.60 \pm 5.06^{a}$ \\
\hline Concentration of LH at peak (mIU/ml) \pm SE & $0.72 \pm 0.08^{a}$ & $0.96 \pm 0.12^{a}$ & $0.71 \pm 0.10^{a}$ \\
\hline
\end{tabular}

\section{Discussion}

The percentage of does that responded to the estrus synchronization treatments were not significantly different $(P>0.05)$ between the three treatment groups. However, treatment PG14 showed lower percentages of response compared to the group with PMSG administration regardless of the duration of insertion; $100 \%$ of does in the latter treatment exhibited estrus within $24 \mathrm{~h}$ to $72 \mathrm{~h}$ after CIDR removal and hormone treatment. This may be due to the absence 
of PMSG in the PG14 treatment group, PMSG plays a major role in stimulating follicular growth and subsequently leads to higher estrus response (Greyling and Van Niekerk, 1990a). This result was also in agreement with Oliveira et al. (2001) which were $100 \%$ of the Saanen does in their study expressed estrus when treated for 9 days with CIDR in combination with 100 IU of eCG and $0.05 \mathrm{mg}$ of Cloprostenol at CIDR removal.

\section{PMSG administration helps the estrus synchronization}

The time when the does start showing estrus was not significantly different $(P>0.05)$ among the treatment groups. Most of the does show estrus as early as $24 \mathrm{~h}$ to $28 \mathrm{~h}$ after the CIDR removals. The treatment PMSG14 and PMSG9 showed significantly greater $(P<0.05)$ frequencies $81 \%$ and $69 \%$, respectively, as compared to treatment PG14 which was $61 \%$ of does from this group show estrus behaviour and signs by $24 \mathrm{~h}$ and $28 \mathrm{~h}$ of time. This may be also due to the PMSG administration. Often, PMSG is administered ranges from about $100 \mathrm{IU}$ to 750 IU along with Cloprostenol (Wildeus, 2000; Oliveira et al., 2001; Abdalla et al., 2014). Whitley and Jackson (2004) reported that the inclusion of PMSG during estrus synchronization treatment may decrease the time interval between CIDR removal and the onset of estrus. The treatment group without PMSG showed a later occurrence of onset of estrus. Some of the onsets of estrus were only starting at $52 \mathrm{~h}$ after progestagen treatment. The results of the onset of estrus following progestagen withdrawal were not significantly different $(P>0.05)$. The overall mean, 28.6 $\pm 0.93 \mathrm{~h}$ was shorter than the result of Motlomelo et al. (2002), Hashemi and Safdarian (2018), and Romano (2004) who reported intervals of $30.1 \pm 5.5 \mathrm{~h}, 36 \mathrm{~h}$, and $40.2 \pm 10.5 \mathrm{~h}$, respectively. The differences in estrus duration reported by the different research probably contributed by several factors such as breed, nutrition, and environment (Ahmed et al., 1998; Motlomelo et al., 2002; Lehloenya et al., 2005).

The duration of estrus obtained from this study was shorter ( $24.5 \pm 2.32$ to $29.6 \pm 1.42 \mathrm{~h}$ ) compared to findings from Motlomelo et al. (2002) $35.2 \pm 0.7 \mathrm{~h}$. Lehloenya et al. (2005) reported the duration of induced estrus in Boer goats was $(37.0 \mathrm{~h})$ longer than the present study. Compared to other types of pessaries such as FGA (fluorogestone acetate) sponge with PMSG, the duration of estrus can go up to $52 \pm 7.8 \mathrm{~h}$. The duration of estrus was longer than $48 \mathrm{~h}$ maybe because the observation time started only at $24 \mathrm{~h}$ and ended at $72 \mathrm{~h}$ after CIDR removal. PMSG helped in tighten the duration of estrus, hence, the estrus could be limit until $72 \mathrm{~h}$ after CIDR removal (Wheaton et al., 1993). As found in a study by Oliveira et al. (2001), the estrus occurrence was only about $24 \mathrm{~h}$ when treated with PMSG which may have promoted the occurrence of a preovulation LH peak and induced premature ovulation. The onset and duration of estrus may also be influenced by breeds, seasons, and nutrition (Dogan et al., 2008).

\section{Estrus behaviour observations}

There were three stages of animal showing estrus behaviour; attractivity, proceptivity, and receptivity. The attractivity and proceptivity behaviour are always expressed together for example sniffing the genitalia area, tail wagging, and mounting behaviour (Beach, 1976). These behaviours are also known as initiation before copulation occurs. During this time, animals usually seek males and try to attract them. The inclusion of PMSG in the estrus synchronization protocol may help in raise the estrogen in blood serum and subsequently facilitate the expression of these estrus behaviour (Imwalle and Katz, 2004). Mounting and standing are the gestures that confirm the animal is in estrus and ready for copulation (Katz and McDonald, 1992). The inclusion of PMSG may also contribute to the high percentage of receptivity behaviour and will result in a higher percentage of fertility. The occurrence of receptivity behaviour (standing to be mounted) is always supported with mounting behaviour. These behaviours are also related to the occurrence of the pre-ovulatory LH surge. Fabre-Nys and Martin (1991) reported that the pre-ovulatory LH surge falls within the time of proceptive and receptive behaviour in does. These behaviours were analyzed and it showed no significant differences between each treatment group. The range time of mounting and standing behaviour which were between $32 \mathrm{~h}$ and $44 \mathrm{~h}$ ) might influence the LH peak to fall within this range of time. 
Comparing the time of CIDR in the vagina, 14 or 9 days did not give any significant difference in does express estrus behaviour, especially the receptivity behaviour. It is because the duration of progesterone contained device like CIDR in the vagina may not differ in the effects. After all, it was the same route although different duration. Another study had been reported, that the time of P4 hormone administration or duration did not significantly affect the receptivity behaviour in goats, but the latter was influenced by seasons and route of administration (Billings and Katz, 1999).

\section{Hormonal pattern after the drug administrations}

The P4 hormone concentration showed no differences among sampling time (before CIDR insertion and $24 \mathrm{~h}$ after CIDR removal). It was relatively low for all treatment groups after CIDR removal with a range of 0.302 to $7.705 \mathrm{ng} / \mathrm{ml}$. These data were in agreement with (Greyling and Van der Nest, 2000) who reported that the ranges of the P4 hormone after intravaginal device being removed as 0.01 to $9.05 \mathrm{ng} / \mathrm{ml}$. In contrast, the study from (Greyling and Van Niekerk, $1990 \mathrm{~b}$ ) had reported the concentrations of P4 hormone during the onset of estrus ranged between 0.35 and $0.6 \mathrm{ng} / \mathrm{ml}$ in Boer goat. Probably the standard concentrations being provided by the manufacturer of the ELISA kit which has ranges $0 \mathrm{ng} / \mathrm{ml}$ to $50 \mathrm{ng} / \mathrm{ml}$ of P4 hormone concentration might have affected the variation and the sensitivity of the antibody in the kit. Greyling and Van Niekerk (1990b) had used, modified method from Van der Westhuysen (1979) which was used ranges $0-10 \mathrm{ng} / \mathrm{ml}$ of P4 hormone concentration. During the time of estrus, the P4 hormone concentration should remain low to trigger the LH surge and subsequently ovulation occurred. The P4 hormone concentration will decrease as the time approaching ovulation due to the administration of Cloprostenol (Fonseca et al., 2008).

The time interval between CIDR removal and LH peak occurrence was varied among the treatment groups. It may be due to different types of hormones used for synchronization. The administration of PMSG fastens the occurrence of the preovulatory LH peak (Pierson et al., 2001). The PMSG contained glycoprotein hormone that would possess the FSH as well as LH. However, the time interval between the onset of estrus and LH peak occurrence showed no differences $(P>0.05)$ between each treatment group. The ranges of time interval onset of estrus to the occurrence of the LH peak were $4 \mathrm{~h}$ to $20 \mathrm{~h}$ and it was in agreement with Baril and Vallet (1990) who reported the interval about $4 \mathrm{~h}$ to $16 \mathrm{~h}$ and $4 \mathrm{~h}$ to $28 \mathrm{~h}$ for breeding and nonbreeding season, respectively.

The LH peak concentrations of this study were contradicted with Gaafar et al. (2005) that had been reported the concentration was about $33.6 \mathrm{mlU} / \mathrm{ml}$ and $59.3 \mathrm{mlU} / \mathrm{ml}$. While this study only recorded a maximum concentration of about $1.06 \mathrm{mlU} / \mathrm{ml}$. It was different probably because the method of hormone detection was different. Gaafar et al. (2005) was using Radioimmunoassay (RIA) kit compared to this study using different methods (ELISA) kit. On the other hand, it also may be due to the sensitivity of the ELISA kit $\left(C U S A B I{ }^{\circledR}\right)$ were not enough to detect the LH surge in the blood serum. Martínez-Álvarez et al. (2007) reported, the variation of the time interval between progestagen treatment and the onset of estrus, LH peak, and ovulation was affected by the type of progestagen, route of administration and dose of drugs being used, and duration of treatment. The ovulation time is unknown and is only predicted by the occurrence of the LH peak. However, the ranges of time for the occurrence of the LH peak were still relevant to other studies mentioned above.

\section{Conclusion}

In a nutshell, the suitable protocol estrus synchronization that farmers may choose is protocol 14 or 9 days of CIDR in conjunction with PG and PMSG because it gives a better success rate in Boer does showing estrus behaviour compared to protocol group without PMSG. The administration of PMSG may help in tighten estrus and improved fertility Boer goat does. 


\section{Acknowledgements}

The project was funded by Exploratory Research Grant Scheme (ERGS/1/11/STWN/UPM/02/15). The authors would like to thank all the people who were involved directly or indirectly in the work effort in the planning, conducting, reporting, and reviewing of this research paper. The authors also thank Dr. Johari Jiken Abdullah, Advance Reproductive Biotechnology (ARB) field staff and National Animal Embryo Centre (NAEC), MARDI, Malaysia technical staff who helped a lot in managing the animals and in the experimental procedures.

\section{References}

Abdalla E, Farrag B, Hashem A, Khalil F, Abdel-Fattah M. Effect of progestagen, PGF2a, PMSG and GnRH on estrus synchronization and some reproductive and productive traits in Barki ewes. Journal of Agroalimentary Processes and Technologies. 2014;20(1):93-101.

Ahmed MM, Makawi S, Jubara A. Synchronization of oestrus in Nubian goats. Small Rumin Res. 1998;30(2):113-20. http://dx.doi.org/10.1016/S0921-4488(98)00104-7.

Baril G, Vallet J. Time of ovulations in dairy goats induced to superovulate with porcine follicle stimulating hormone during and out of the breeding season. Theriogenology. 1990;34(2):303-11. http://dx.doi.org/10.1016/0093-691X(90)90523-V. PMid:16726839.

Beach FA. Sexual attractivity, proceptivity, and receptivity in female mammals. Horm Behav. 1976;7(1):105-38. http://dx.doi.org/10.1016/0018-506X(76)90008-8. PMid:819345.

Billings $\mathrm{H}$, Katz L. Facilitation of sexual behavior in French-Alpine goats treated with intravaginal progesterone-releasing devices and estradiol during the breeding and nonbreeding seasons. J Anim Sci. 1999;77(8):2073-8. http://dx.doi.org/10.2527/1999.7782073x. PMid:10461984.

Dogan I, Konyali A, Tolu C, Yurdabak S. Different estrous induction protocols during the transition period in lactating Turkish Saanen does following Al. Acta Vet (Beogr). 2008;58(2-3):259.

Fabre-Nys C, Martin GB. Hormonal control of proceptive and receptive sexual behavior and the preovulatory LH surge in the ewe: reassessment of the respective roles of estradiol, testosterone, and progesterone. Horm Behav. 1991;25(3):295-312. http://dx.doi.org/10.1016/0018-506X(91)90003Z. PMid:1937424.

Fonseca JF, Torres CAA, Santos A, Maffili V, Amorim L, Moraes E. Progesterone and behavioral features when estrous is induced in Alpine goats. Anim Reprod Sci. 2008;103(3-4):366-73. http://dx.doi.org/10.1016/j.anireprosci.2007.05.013. PMid:17611052.

Gaafar KM, Gabr MK, Teleb DF. The hormonal profile during the estrous cycle and gestation in Damascus goats. Small Rumin Res. 2005;57(1):85-93. http://dx.doi.org/10.1016/j.smallrumres.2004.07.009.

Greyling J, Van Niekerk C. Effect of pregnant mare serum gonadotrophin (PMSG) and route of administration after progestagen treatment on oestrus and $\mathrm{LH}$ secretion in the Boer goat. Small Rumin Res. 1990a;3(5):511-6. http://dx.doi.org/10.1016/0921-4488(90)90082-H.

Greyling J, Van Niekerk C. Ovulation in the Boer goat doe. Small Rumin Res. 1990b;3(5):457-64. http://dx.doi.org/10.1016/0921-4488(90)90076-I.

Greyling JP, Van der Nest M. Synchronization of oestrus in goats: dose effect of progestagen. Small Rumin Res. 2000;36(2):201-7. http://dx.doi.org/10.1016/S0921-4488(99)00165-0. PMid:10760457.

Hashemi M, Safdarian M. Efficiency of different methods of estrus synchronization followed by fixed time artificial insemination in Persian downy does. Animal Reproduction (AR). 2018;14(2):413-7. http://dx.doi.org/10.21451/1984-3143-AR825.

Hifzan RM, Idris I, Yaakub H. Growth pattern for body weight, height at withers and body length of kalahari red goats. Pak J Biol Sci. 2015;18(4):200-3. http://dx.doi.org/10.3923/pjbs.2015.200.203. PMid:26506652.

Imwalle DB, Katz LS. Divergent roles for estrogens and androgens in the expression of female goat sexual behavior. Horm Behav. 2004;46(1):54-8. http://dx.doi.org/10.1016/j.yhbeh.2004.01.008. PMid:15215042.

Katz LS, McDonald T. Sexual behavior of farm animals. Theriogenology. 1992;38(2):239-53. http://dx.doi.org/10.1016/0093-691X(92)90233-H. PMid:16727133.

Kilkenny C, Browne W, Cuthill IC, Emerson M, Altman DG, NC3Rs Reporting Guidelines Working Group. Animal research: reporting in vivo experiments: the ARRIVE guidelines. Br J Pharmacol. 2010;160(7):1577-9. http://dx.doi.org/10.1111/j.1476-5381.2010.00872.x. PMid:20649561. 
Lehloenya K, Greyling J, Schwalbach L. Reproductive performance of South African indigenous goats following oestrous synchronisation and Al. Small Rumin Res. 2005;57(2):115-20. http://dx.doi.org/10.1016/j.smallrumres.2004.05.004.

Lu, C. D. Boer goat production: progress and perspective [Internet]. USA: Iga goatworld; 2001 [cited 2020 Nov 25]. Available from: Org/publication/boer.htm

Martinez MF, Kastelic J, Adams G, Mapletoft R. The use of a progesterone-releasing device (CIDR-B) or melengestrol acetate with $\mathrm{GnRH}$, $\mathrm{LH}$, or estradiol benzoate for fixed-time Al in beef heifers. J Anim Sci. 2002;80(7):1746-51. http://dx.doi.org/10.2527/2002.8071746x. PMid:12162641.

Martínez-Álvarez LE, Hernández-Cerón J, González-Padilla E, Perera-Marín G, Valencia J. Serum LH peak and ovulation following synchronized estrus in goats. Small Rumin Res. 2007;69(1-3):124-8. http://dx.doi.org/10.1016/j.smallrumres.2005.12.024.

Maynard JN. Live and carcass characteristics of boer-and savannah-cross kid buckling goats fed dried distillers grain with solubles [thesis]. Ohio: The Ohio State University; 2015.

Motlomelo K, Greyling J, Schwalbach L. Synchronisation of oestrus in goats: the use of different progestagen treatments. Small Rumin Res. 2002;45(1):45-9. http://dx.doi.org/10.1016/S09214488(02)00113-X.

Oliveira LZ, Martins Hossepian de Lima VF, Oliveira CS, Alves BG, Graff HB, dos Santos RM. Fertility rates following fixed-time artificial insemination in dairy heifers in a practical progesterone-based protocol. Acta Sci Vet. 2011;39(2):964.

Oliveira MA, Guido S, Lima P. Comparison of different protocols used to induce and synchronize estrus cycle of Saanen goats. Small Rumin Res. 2001;40(2):149-53. http://dx.doi.org/10.1016/S09214488(00)00222-4. PMid:11295397.

Pierson JT, Baldassarre H, Keefer C, Downey B. Seasonal variation in preovulatory events associated with synchronization of estrus in dwarf goats. Theriogenology. 2001;56(5):759-69. http://dx.doi.org/10.1016/S0093-691X(01)00605-7. PMid:11665879.

Rahman ANMA, Abdullah RB, Khadijah WEW. A review of reproductive biotechnologies and their application in goat. Biotechnology (Faisalabad). 2008b;7(2):371-84. http://dx.doi.org/10.3923/biotech.2008.371.384.

Rahman ANMA, Abdullah RB, Wan-Khadij WE. Estrus synchronization and superovulation in goats: a review. J Biol Sci. 2008a;8(7):1129-37. http://dx.doi.org/10.3923/jbs.2008.1129.1137.

Romano J. Synchronization of estrus using CIDR, FGA or MAP intravaginal pessaries during the breeding season in Nubian goats. Small Rumin Res. 2004;55(1):15-9. http://dx.doi.org/10.1016/j.smallrumres.2003.10.015.

Salleh S, Yaakub H, Panandam J. Progesterone and luteinising hormone profile of Saanen crossbred goats synchronised with CIDR and PMSG. Malays J Anim Sci. 2014;17(1):95-102.

Van der Westhuysen J. The control of ovarian function in cycling and anoestrous Angora goat does. Agroanimalia. 1979;11:23-35.

Wheaton JE, Carlson KM, Windels HF, Johnston LJ. CIDR: a new progesterone-releasing intravaginal device for induction of estrus and cycle control in sheep and goats. Anim Reprod Sci. 1993;33(1):12741. http://dx.doi.org/10.1016/0378-4320(93)90111-4.

Whitley, N. C. and D. Jackson. An update on estrus synchronization in goats: a minor species. J Anim Sci. 2004;82(E-suppl):E270-6. http://dx.doi.org/10.2527/2004.8213_supplE270x. PMID: 15471808.

Wildeus S. Current concepts in synchronization of estrus: sheep and goats. J Anim Sci. 2000;77(ESuppl):1-14. http://dx.doi.org/10.2527/jas2000.00218812007700ES0040x.

Zeleke M, Greyling J, Schwalbach L, Muller T, Erasmus J. Effect of progestagen and PMSG on oestrous synchronization and fertility in Dorper ewes during the transition period. Small Rumin Res. 2005;56(1):47-53. http://dx.doi.org/10.1016/j.smallrumres.2003.12.006.

\section{Author contributions}

HY: Conceptualization, Funding acquisition, Supervision, Writing - original draft, Writing - review \& editing; SMS: Data curation, Formal analysis, Methodology, Writing - original draft, Writing - review \& editing; AMHB: Data curation, Formal analysis. All authors wrote, read, and approved the final version of the manuscript. 